\title{
Synthesis and Characterization of a Nano-Adsorbent Derivative Derived from Grape Seeds for Cadmium Ion Removal in an Aqueous Solution
}

\author{
Alaa Jasim Mohammed ${ }^{1}$, Mohd Hafiz Ibrahim ${ }^{1, *}$, Syaizwan Zahmir Zulkifli ${ }^{1}$ (D) and Jasim Mohammed Salman ${ }^{2}$ \\ 1 Department of Biology, Faculty of Science, Universiti Putra Malaysia, Serdang 43400, Selangor, Malaysia; \\ jasimalaa62@yahoo.com (A.J.M.); syaizwan@upm.edu.my (S.Z.Z.) \\ 2 Department of Energy, Faculty of Engineer, Iraq University College, Basrah 61001, Iraq; \\ jassim.salman@iuc.edu.iq \\ * Correspondence: mhafiz_ibrahim@upm.edu.my
}

check for updates

Citation: Mohammed, A.J.; Ibrahim, M.H.; Zulkifli, S.Z.; Salman, J.M. Synthesis and Characterization of a Nano-Adsorbent Derivative Derived from Grape Seeds for Cadmium Ion Removal in an Aqueous Solution. Water 2021, 13, 2896. https: / / doi.org/10.3390/w13202896

Academic Editors: Antonio Zuorro and Laura Bulgariu

Received: 14 August 2021

Accepted: 27 September 2021

Published: 15 October 2021

Publisher's Note: MDPI stays neutral with regard to jurisdictional claims in published maps and institutional affiliations.

Copyright: (c) 2021 by the authors. Licensee MDPI, Basel, Switzerland. This article is an open access article distributed under the terms and conditions of the Creative Commons Attribution (CC BY) license (https:/ / creativecommons.org/licenses/by/ $4.0 /)$.

\begin{abstract}
Grape seeds were utilized as a source for nanoparticle adsorbents. The objective of this work was to prepare a nano adsorbent from grape seeds (GS) and $\mathrm{FeCl}_{2}$. The physical and chemical properties of grape seed ferrous oxide nanoparticles (GS-IONPs) were investigated. Batch adsorption was used to investigate the adsorption of cadmium from industrial water with different initial concentrations, solution $\mathrm{pH}$ and contact time. The adsorption isotherm data for Cd(II) on GS-IONPs were fitted to the Langmuir, Freundlich, and Temkin isotherm models. The data fit the Langmuir model well, with a maximum cadmium uptake of $16.3 \mathrm{mg} / \mathrm{g}$. It was found that \%removal of cadmium decreased from $98.0 \%$ to $88.0 \%$ as the initial concentration increased. The results revealed that the prepared adsorbent was effective in Cd(II) removal.
\end{abstract}

Keywords: grape seeds; nanoparticles adsorbent; cadmium; adsorption; isotherm models

\section{Introduction}

Heavy metals, poisonous polyaromatic hydrocarbons, and trace elements are all present in tobacco smoke, which is a big problem. The advantages are primarily tied to the negative health effects of lead $(\mathrm{Pb})$, arsenic $(\mathrm{As})$, chrome $(\mathrm{Cr})$, nickel $(\mathrm{Ni})$, and cadmium $(\mathrm{Cd})$. Heavy metals from tobacco may be transferred through smoke and smoke condensation [1]. After long-term (10-12 years) exposure to smoking, both lead and cadmium accumulate in tissues and fluids. Organic monitoring studies revealed that smokers had much higher levels of lead and cadmium than non-smokers. Metal bioaccumulation has also been observed in non-smokers who are exposed to second-hand smoke regularly [2].

Furthermore, anthropogenic behaviors from natural sources, increased industrialization, urbanization, energy production, poor waste management, and other anthropogenic reasons at the local or regional level all contribute, either directly or indirectly, to heavy metal contamination of the global environment [3]. As a result of human activities, heavy metals have been released into the atmosphere, and they may permeate the soil layer and the marine ecosystem via both dry and wet deposition processes. Cadmium, chromium, cobalt, copper, nickel, lead, and zinc, as well as soil and marine ecosystems, have the potential to have substantial ecological implications and pose a risk to human health [4]. Because of their toxicity, heavy metals are harmful to humans and a number of biological receptors. In order to conduct an accurate analysis and detect potential threats to human health, heavy metal concentrations in soil, groundwater, and air ecosystems must be monitored and assessed [5].

Moreover, some heavy metal tolerance limits are listed in Table 1, while others (such as arsenic, cadmium, lead, and methylation forms of mercury) have been claimed to have no known bio-importance in human biochemistry and can be harmful even at very low 
quantities. Even for bio-important nutrients, dietary intakes must be kept below regulatory limits, since excesses can cause poisoning or toxicity, as evidenced by certain clinically diagnosable medical symptoms [6].

Table 1. American environmental protection agency, heavy metals levels [7].

\begin{tabular}{cccc}
\hline Heavy Metals & M.C. in Air (ppm) & M.C. in Soil (ppm) & $\begin{array}{c}\text { M.C. in Drinking Water } \\
\text { (ppm) }\end{array}$ \\
\hline $\mathrm{Cd}$ & $0.1-0.2$ & 85 & 0.005 \\
\hline $\mathrm{Pb}$ & - & 420 & 0.01 \\
\hline $\mathrm{Zn}$ & $1.5^{*}$ & 7500 & 5.00 \\
\hline $\mathrm{Hg}$ & - & $\leq 1$ & 0.002 \\
\hline $\mathrm{Ca}$ & 5 & Tolerable & 50 \\
\hline $\mathrm{Ag}$ & 0.01 & - & 0.0 \\
\hline $\mathrm{AS}$ & - & - & 0.1 \\
\hline
\end{tabular}

${ }^{*}$ M.C.: maximum contamination levels.

Plants grown in wastewater-irrigated soil had significantly greater heavy metal concentrations than those grown in reference soil $(p=0.001)$, as well as significantly higher concentrations than those grown in soil that had not been irrigated with wastewater. Values below the World Health Organization's (WHO) allowed limits for health risk index indicated that there were few health concerns associated with eating contaminated vegetables [8-12].

Heavy metal removal from water and wastewater is a worldwide problem that must be addressed [13]. Heavy metals are absorbed into the human body via the food chain and accumulate in tissues. They have the potential to cause significant health issues [14]. Chemical precipitation/coagulation, membrane technology, electrolytic reduction, ion exchange, and adsorption have all been investigated in various research for heavy metal adsorption. This is due to the simplicity with which their surface functionality may be modified, as well as their large surface area to volume ratio, which allows for increased adsorption capacity and efficiency. Cadmium is a naturally occurring radioactive metal that is widely distributed through manufacturing environments, plant soils, and smoking. Even when small quantities of cadmium are discovered, overexposure can occur due to its low permissible human toxicity. Cadmium is often used in electroplating, but the procedure itself does not always result in overexposure. It is also present in several vehicle paints and can be dangerous when sprayed. Cadmium paint removal operations that require scraping or blasting might be dangerous. In addition, cadmium is primarily used as a by-product of zinc metal processing in the production of NiCd rechargeable batteries [15].

Cadmium, a heavy metal with high toxicity, is a serious environmental and occupational danger. It is found in the Earth's crust at a concentration of roughly $0.1 \mathrm{mg} / \mathrm{kg}$ and is extensively distributed over the globe. When it comes to cadmium in the environment, sediments have the highest concentrations, while marine phosphates have about $15 \mathrm{mg} / \mathrm{kg}$ of cadmium. Cadmium is utilized in the production of a wide range of items, including batteries, alloys, and pigments [16]. Despite fast developments in the use of cadmium in batteries, due to environmental concerns, commercial use of the metal has declined in developed countries [17].

Regardless, a range of chemical and physical technical procedures have been developed and used to remove large amounts of each potentially dangerous heavy metal from wastewater. Chemical precipitation, ion exchange, membrane filtration, electrochemical treatment technologies, and adsorption are some of the techniques used. The adsorption process has gained popularity due to its efficacy in eliminating impurities; also, adsorption produces high-quality goods and is a cost-effective method [18]. Low cost, widespread 
availability, simple design, high effectiveness, ease of operation, biodegradability, and ability to concentrate pollutants are all advantages of adsorption over other options [19].

However, while activated carbon adsorption is the most extensively used wastewater treatment method, nanoparticles utilized as adsorbents offer adsorption an edge. Nanoparticles (NPs) are useful for improving wastewater treatment and supplementing water supplies by utilizing unconventional water sources. Various nano adsorbents often employed in wastewater treatment are comprehensively described for the goal of removing various types of contaminants utilizing nano adsorbents, with a special emphasis on nano adsorbent regeneration [20]. NPs are a subclass of nanomaterials that, due to their unique features and wide range of applications, are currently at the forefront of cutting-edge research in practically every sector imaginable [21]. Because of their exceptional magnetic characteristics and minimal toxicity, magnetic iron oxide nanoparticles (MIONPs) have received a lot of attention.

Nanoparticles are materials with special properties that can be applied in different fields, such as medicine, engineering, food industry and cosmetics. The contributions regarding the synthesis of different types of nanoparticles have allowed researchers to determine a special group of nanoparticles with key characteristics for several applications [22]. The production of silver nanoparticles (Ag-NPs) from bilberry waste (BW) and red currant waste (RCW) extracts was studied by other researchers [23].

Magnetic composite synthesized from iron oxide $\left(\gamma \mathrm{Fe}_{2} \mathrm{O}_{3}\right.$ or $\left.\mathrm{Fe}_{2} \mathrm{O}_{4}\right)$ and hydroxyapatite. It was obtained applying some methods, i.e., chemical precipitation, hydrothermal, sol-gel, and biomimetic or combined techniques which exhibit characteristic properties affecting the form of the prepared product $[24,25]$.

There are numerous distinct morphologies, sizes, and particle size distributions in the most prevalent oxides in which IONPs exist in nature, and there are many alternative synthetic ways to create them. Moreso, due to the presence of two cations $\left(\mathrm{Fe}^{2+}\right.$ and $\left.\mathrm{Fe}^{3+}\right)$ in their crystal structure, magnetic $\mathrm{Fe}_{3} \mathrm{O}_{4}$ and $\mathrm{Fe}_{2} \mathrm{O}_{3}$ are commonly utilized nanoparticles (NPs) with distinctive features. The corundum structure is found in $\mathrm{Fe}_{2} \mathrm{O}_{3}$, while the spinel structure is found in the other two. Because $\mathrm{Fe}_{2} \mathrm{O}_{3}$ and $\mathrm{Fe}_{3} \mathrm{O}_{4}$ are metastable in an oxidizing environment, they will be oxidized to $\mathrm{Fe}_{2} \mathrm{O}_{3}$ by heating above $400{ }^{\circ} \mathrm{C}$. IONPs have been explored extensively for their varied uses in disciplines such as medicine, information technology, and the environment. In this study, grape seeds and $\mathrm{FeCl}_{2}$ were used to make a new type of nanoparticle that was used as an adsorbent for the removal of cadmium.

\section{Materials and Methods}

\subsection{Materials}

Grape seeds (GS) were acquired from Iraqi markets and used as starting materials for the adsorbent preparation reaction with ferrous chloride. Grape seeds were washed thoroughly to remove dirt and deposits from their surfaces, then dried at $100^{\circ} \mathrm{C}$ for $24 \mathrm{~h}$.

\subsection{Adsorbant}

Technical grade of cadmium Cd(II) at a concentration of $(1000 \mathrm{mg} / \mathrm{L})$ was used as adsorbate in this work, and was supplied by Scharlaw Chiemi, S.A., Barcelona, Spain.

\subsection{Biosynthesis of Grape Seeds Iron Oxide Nanoparticles GS-IONPS}

Preparation $0.1 \mathrm{M}$ ferrous chloride is made by dissolving $12.67 \mathrm{~g}$ of $\mathrm{FeCl}_{2}$ in $1000 \mathrm{~mL}$ of deionized water, stirring for $20 \mathrm{~min}$, and storing at $20{ }^{\circ} \mathrm{C}$ for further use. The grape seed extract was found to be effective at converting iron ions like sulfate and chlorides to their oxides. Because grape seeds extract has a significant amount of polyphenol chemicals, it was used to make iron oxide nanoparticles (IONPs) under various $\mathrm{pH}$ conditions and varying ratios of iron salt to grape seed extract. By adding $0.1 \mathrm{M} \mathrm{FeCl}_{2}$ solution to grape seeds extract in a (1:2) volume ratio, IONPs were created. To obtain a colloidal suspension, the liquid was agitated for $60 \mathrm{~min}$ and then allowed to rest at room temperature for another 30 min. To create a mixture of $\mathrm{Fe}_{2} \mathrm{O}_{3}-\mathrm{NPs}$ and $\mathrm{Fe}_{3} \mathrm{O}_{4}-\mathrm{NPs}$, the mixture was centrifuged at 
$16,000 \mathrm{rpm}$, and the precipitate was washed with ethanol three times before being dried at $45^{\circ} \mathrm{C}$ under vacuum. The best reduction capability against ferric chloride is grape seed extract, as seen by the exterior color shift. The best conditions for making GS-IONPs were found to be a volume mixing ratio of $0.1 \mathrm{M} \mathrm{FeCl}_{2}$ with grape seed extract $(2: 1)$ at $70{ }^{\circ} \mathrm{C}$ and $\mathrm{pH}$ of 3.8.

\subsection{Characterization of the Prepared Grape Seeds Iron Oxide Nanoparticles GS-IONPS}

Laser diffraction particle size analyzers (Malvern, England) was used to determine the precise particle size distributions for Nanoparticle adsorbent (NPA). Scanning electron microscope (Tescan Vega III, Czech) analysis was utilized to confirm the morphological properties of the NPA, which were described using a Tescan Vega I scanning electron microscope. X-ray diffraction (Shimadzu XRD-6000 small, multi-functional ray diffractometers, Shimadzu, Tokyo, Japan) was designed for acquiring the highest quality diffraction data while also being simple to use and flexible enough to switch between different GS-IONP applications rapidly. The ABB-Spectro-Lab-MB3000-FTIR (Clairet Scientific, Northampton, UK) spectrometer was utilized to analyze the surface chemistry of the produced NPA using attenuated total reflectance, Fourier Transform Infrared spectroscopy (FTIR).

\subsection{Adsorption Studies}

For batch adsorption, four $(250 \mathrm{~mL})$ Erlenmeyer flasks were used. In a typical adsorption run, $200 \mathrm{~mL}$ of Cd solutions with initial concentrations of $10-25 \mathrm{mg} / \mathrm{L}$ were put into these flasks. These flasks were filled with a constant amount $(0.30 \mathrm{~g})$ of prepared GS-IONPs and shaken at $30^{\circ} \mathrm{C}$ in an isothermal shaker $(120 \mathrm{rpm})$ until equilibrium was established. The concentrations of cadmium solutions before and after adsorption were determined using an atomic absorption spectrophotometer from Shimadzu, Japan. The quantity of adsorption at equilibrium, $\mathrm{q}_{\mathrm{e}}(\mathrm{mg} / \mathrm{g})$, was as follows:

$$
\mathrm{q}_{\mathrm{e}}=\left(\mathrm{C}_{\mathrm{o}}-\mathrm{C}_{\mathrm{e}}\right) \mathrm{V} / \mathrm{W}
$$

The liquid-phase concentrations of cadmium at the starting and equilibrium conditions, respectively, are $C_{o}$ and $C_{e}(\mathrm{mg} / \mathrm{L})$. The volume of the solution is $V(\mathrm{~L})$, and the mass of the adsorbent is $\mathrm{W}(\mathrm{g})$.

The following equation was used to compute the \%removal of cadmium at equilibrium:

$$
\% \text { Removal }=\left(\mathrm{C}_{\mathrm{o}}-\mathrm{C}_{\mathrm{e}}\right) / \mathrm{Co} \times 100
$$

\subsection{Adsorption Isotherms}

The equilibrium of heavy metals between the aqueous solution and the solid phase is represented by adsorption isotherms. The isotherm model can specify the optimum adsorption potential and several thermodynamic parameters that can be used to better understand the binding mechanism, based on the design of the adsorption device. The Langmuir [26], Freundlich [27] and Temkin [28] isotherm models were used to fit the adsorption isotherm data. In terms of a dimensionless constant separation factor or equilibrium parameter, $\mathrm{R}_{\mathrm{L}}$, which is defined as the fundamental function of the Langmuir isotherm and indicates the nature of the adsorption process as explained in Table 2.

Table 2. Separation factors.

\begin{tabular}{cc}
\hline RL Value & Nature of Adsorption Process \\
\hline$R L=0$ & Irreversible \\
\hline$R L=1$ & Linear \\
\hline$R L>1$ & Unfavorable \\
\hline $0<R L<1$ & Favorable \\
\hline
\end{tabular}




\section{Results and Discussion}

\subsection{Color Change}

Figure 1 shows the color variations of the produced nanoparticles using grape seeds water extract. After mixing grape seed water extracts with ferrous oxide $0.1 \mathrm{M}$, there was a color change from yellow to black within minutes, as well as an increase in the density and intensity of precipitate, which was gradually increased to reach the highest darkness and density after $36 \mathrm{~h}$ of mixing grape seed water extracts with ferrous oxide $0.1 \mathrm{M}$ (Figure 1). The optimum appearance of nanoparticles biosynthesis was in the tube containing a 2:1 $v / v$ ratio of ferric chloride and grape seed water extract at $\mathrm{pH} 3.8$. The particles formed solidified and precipitated plainly at the tube's bottom.

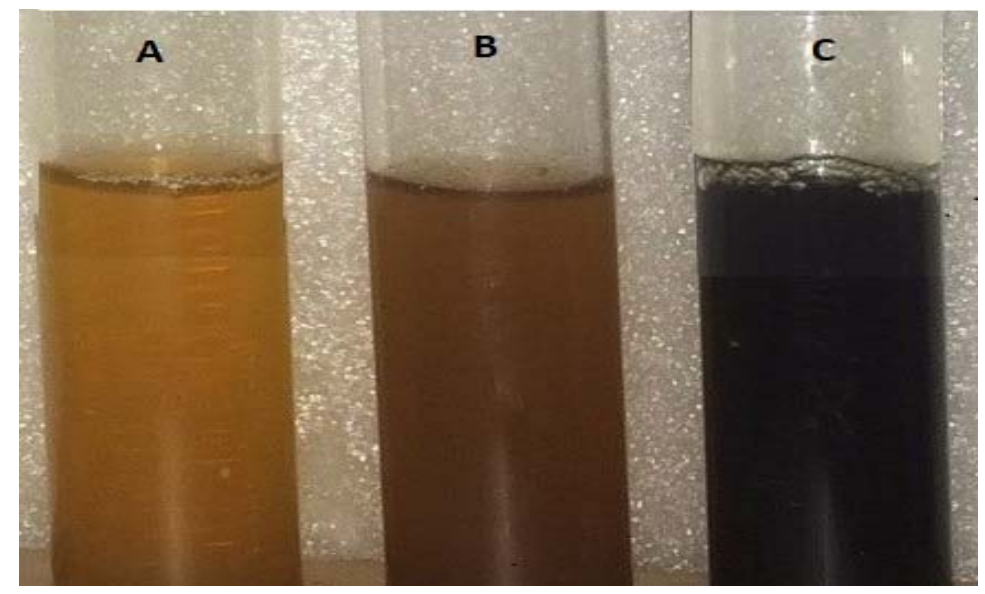

Figure 1. Color changes and density of precipitate formed immediately after mixing of iron salt to grape seeds extract. (A) $5 \mathrm{~min},($ B) $1 \mathrm{~h}$, (C) $36 \mathrm{~h}$.

\subsection{Ultraviolet-Visible Spectroscopy Analysis}

Using a UV-Vis spectrum with a wave light of 190-800 nm, the optical densities of the produced NPs were investigated. The synthesized compounds from grape seeds water extract and iron chloride salt strongly absorbed radiation over a wide range of ultraviolet wavelengths-visible spectra varied from 190 to 800 . The GS-IONPs at acidic $\mathrm{pH}$ had the highest UV absorbance, but all the produced nanoparticles had slightly varying absorbance in visual spectroscopy. UV-Visible spectroscopy examines the absorbance of iron oxide nanoparticles synthesized by grape seeds extract mixing with ferrous chloride and gave the maximum peaks at $\mathrm{pH}=3.8$, ratio of $(2: 1)$ as shown in Figure 2 .

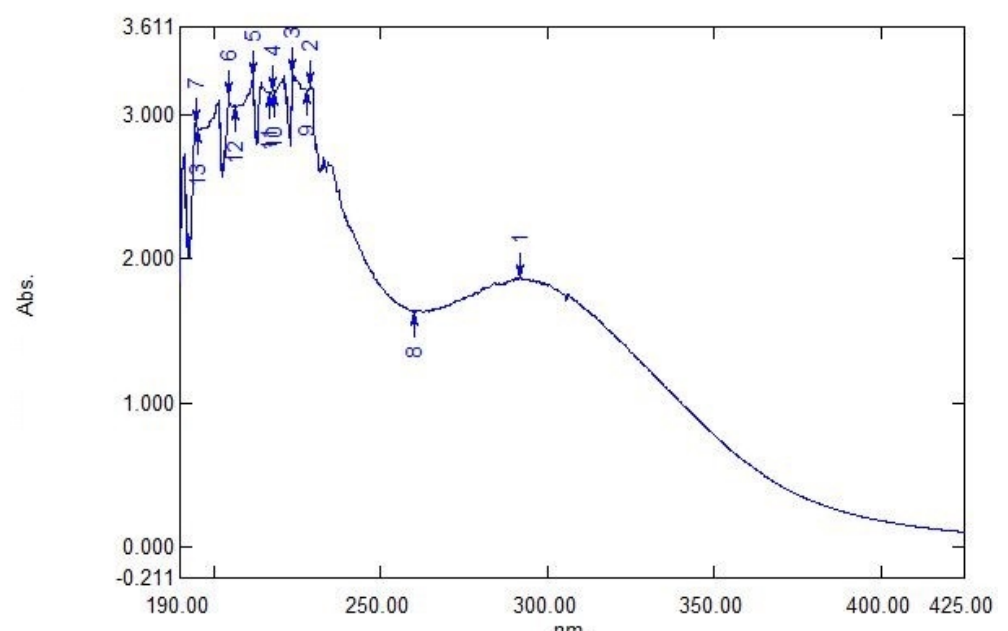

Figure 2. UV-Visible spectroscopy absorbance of iron oxide nanoparticles synthesized by grape seeds extract mixing with ferrous chloride $\mathrm{pH}=3.8$, ratio of $(2: 1)$. 


\subsection{Surface Morphology Analysis}

Scanning electron microscopy was used to examine the adsorbent's surface morphology. Figure 3 shows the SEM micrographs of the GS-IONPs. The unique cubic crystalline form with a range chrysalis size of $36.7-42 \mathrm{~nm}$ was seen in the plate below in a low $\mathrm{pH}$ grape seeds solution. The iron oxide nanoparticles created agglomerated particles formed at high $\mathrm{pH}$.

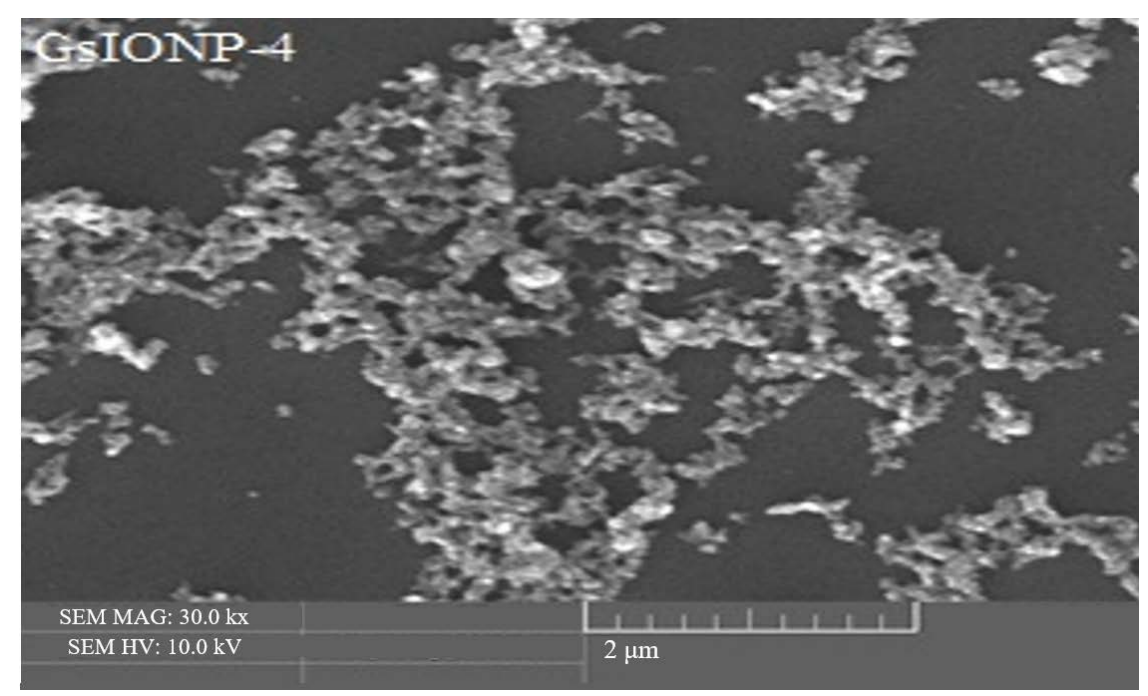

Figure 3. SEM images of nanoparticles synthesis GS-IONPs, (GS extract mixing with ferrous chloride at $\mathrm{pH}$ of 3.8 and volume ratio of $2: 1$ ).

\subsection{Fourier Transforms Infrared (FTIR) Analyses}

FTIR spectroscopy (ABB/Spectro, lab/MB3000/UK) was used to examine grape seeds (GS) and iron oxide nanoparticles (IONPs). The FTIR spectrums of the GS and GS-IONPs were shown in Figures 4 and 5, respectively. The key trend in the FTIR spectrum is the detection of diverse functional groups on surfaces as well as the appearance of new functional groups in the Nano adsorbent. This was due to the thermal degradation impact during the $\mathrm{FeCl}_{2}$ mixing procedures, which caused certain intermolecular bonds to be destroyed.

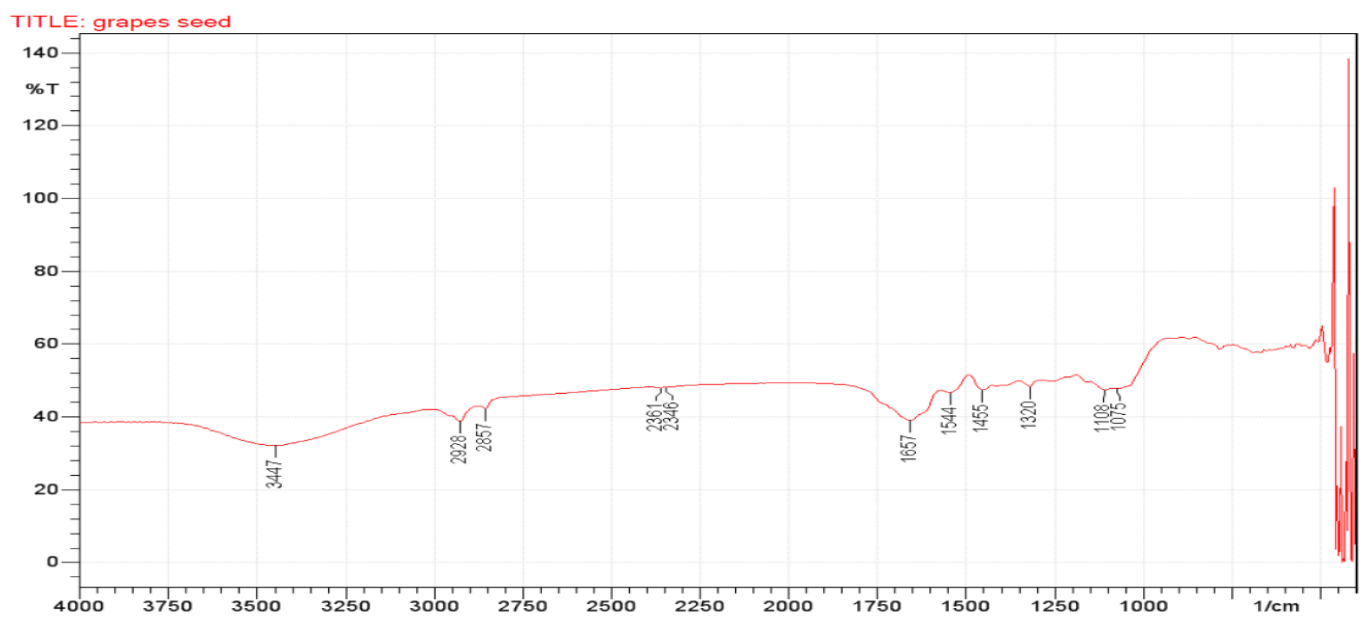

Figure 4. FTIR spectrum of grape seeds (GS). 


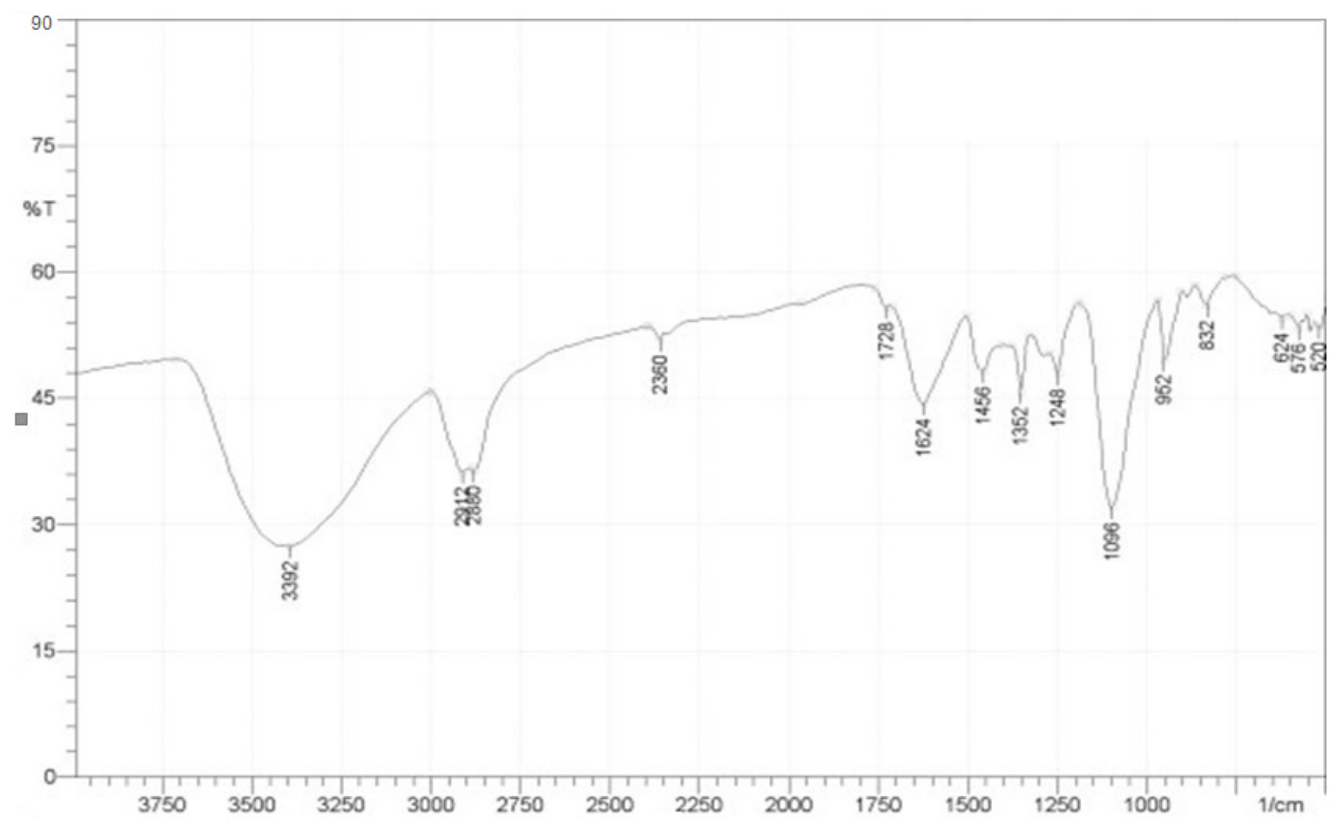

Figure 5. FTIR spectrum of iron oxide nanoparticles synthesis by grape seed extract under (GS water extract mixing with ferrous chloride (GS-IONPs) at $\mathrm{pH} 3.8$ and ratio 2:1).

Consequently, the rotational vibrations due to distinct IR absorption according to wavelength $\left(\mathrm{cm}^{-1}\right)$ were allocated for vibrations appearing between 4000 and 2500, 2500 and 200, and 200 and $1500 \mathrm{~cm}^{-1}$, according to the examination of the FTIR spectrum images for the present manufactured GS-IONPs displayed in Figure 5. The findings demonstrated that the grape seed water extract-prepared iron oxide nanoparticles contained components rich in $\mathrm{O}-\mathrm{H}, \mathrm{C}-\mathrm{C}, \mathrm{N}-\mathrm{H}$, and $\mathrm{COOH}$ at an IR absorption range of $3400-1500 \mathrm{~cm}^{-1}$, as well as an absorption in the fingerprint area of $750-529 \mathrm{~cm}^{-1}$, which was specific for iron oxide limits.

\subsection{X-ray Diffraction Analysis}

Patterns of XRD have long been utilized to characterize important aspects of a compound, such as the types and nature of crystalline phases present. The theta- 2 values of the distinct peaks in Figure 6 were included in the XRD analysis. Nevertheless, according to the type of iron oxide generated, the pattern of IONPs synthesized from grape seed extract revealed sharp diffraction peaks at 2 angles. When compared to JCPDS data, the phase identification and crystalline structure of nanoparticles, as well as the determination of the strong diffraction peak with theta-2 values of $26.618^{\circ}, 33.8515^{\circ}, 35.05^{\circ}, 39.07^{\circ}, 46.375^{\circ}$, and $55.7^{\circ}$, can be indexed to a mixture of iron oxides viz gamma- $\mathrm{Fe}_{2} \mathrm{O}_{3}$ (magnetite, tetragonal).

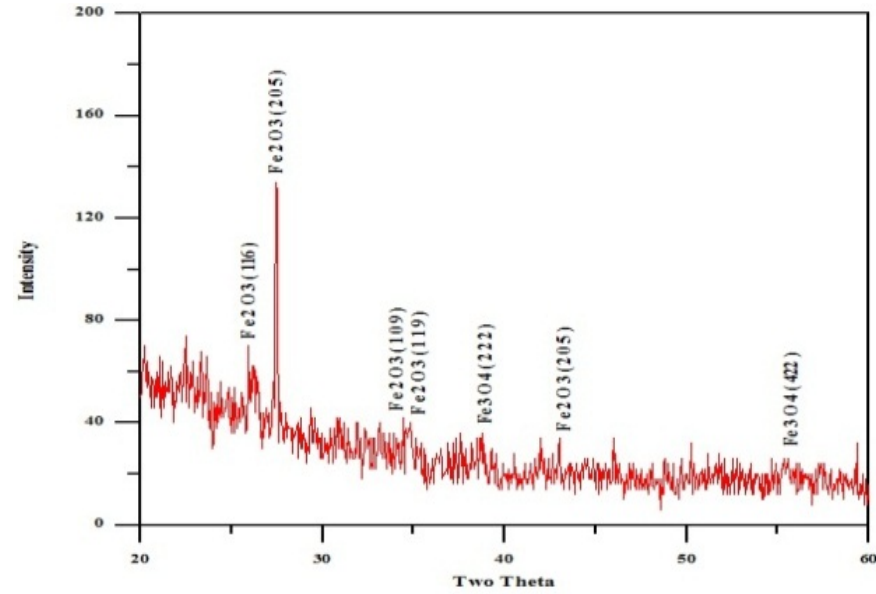

Figure 6. XRD spectrum of nanoparticles synthesis (GS-IONPs). 


\subsection{Adsorption Isotherms}

To approximate the adsorption data in general, the Langmuir, Freundlich, and Temkin isotherm models were utilized for the adsorption of cadmium onto GS-IONPs and commercial charcoal as shown in (Table 3). The suitability of isotherm models for fitting the adsorption data was verified by comparing values of correlation coefficients $\left(\mathrm{R}^{2}\right)$. The more accurate fit, the closer the $\mathrm{R}^{2}$ value is to one.

Table 3. Langmuir, Freundlich and Temkin isotherm models parameters and correlation factors for the adsorption of cadmium onto GS-IONPs and commercial charcoal at $30{ }^{\circ} \mathrm{C}$.

\begin{tabular}{|c|c|c|c|}
\hline Isotherm Models & \multicolumn{3}{|c|}{ Parameters } \\
\hline \multicolumn{4}{|c|}{ Grape seeds-IONPs (GS-IONPs) } \\
\hline \multirow[t]{2}{*}{ Langmuir } & $\mathrm{q}_{\mathrm{m}}(\mathrm{mg} / \mathrm{g})$ & $\mathrm{Ka}(\mathrm{L} / \mathrm{mg})$ & $\mathrm{R}^{2}$ \\
\hline & 16.13 & 3.425 & 0.999 \\
\hline \multirow[t]{2}{*}{ Freundlich } & $\begin{array}{c}\mathrm{K}_{\mathrm{F}} \\
\left(\mathrm{mg} / \mathrm{g}(\mathrm{L} / \mathrm{mg})^{1 / \mathrm{n}}\right)\end{array}$ & $1 / \mathrm{n}$ & $\mathrm{R}^{2}$ \\
\hline & 2.632 & 0.2999 & 0.913 \\
\hline \multirow[t]{2}{*}{ Temkin } & $\mathrm{A}(\mathrm{L} / \mathrm{g})$ & B & $\mathrm{R}^{2}$ \\
\hline & 2.725 & 2.382 & 0.72 \\
\hline \multicolumn{4}{|c|}{ Commercial charcoal (CC) } \\
\hline \multirow[t]{2}{*}{ Langmuir } & $\mathrm{q}_{\mathrm{m}}(\mathrm{mg} / \mathrm{g})$ & $\mathrm{Ka}(\mathrm{L} / \mathrm{mg})$ & $R^{2}$ \\
\hline & 11.124 & 0.177 & 0.97 \\
\hline \multirow[t]{2}{*}{ Freundlich } & $\begin{array}{c}\mathrm{K}_{\mathrm{F}} \\
\left(\mathrm{mg} / \mathrm{g}(\mathrm{L} / \mathrm{mg})^{1 / \mathrm{n}}\right)\end{array}$ & $1 / \mathrm{n}$ & $\mathrm{R}^{2}$ \\
\hline & 2.731 & 0.481 & 0.91 \\
\hline \multirow[t]{2}{*}{ Temkin } & $\mathrm{A}(\mathrm{L} / \mathrm{g})$ & B & $R^{2}$ \\
\hline & 2.722 & 0.419 & 0.95 \\
\hline
\end{tabular}

The isotherm data were assessed for their design by fitting it to a variety of isotherm models and choosing the best one. The correlation coefficient, $R^{2}$ demonstrates that the Langmuir isotherm model properly reflects the single-layer adsorption process in our system, which has a maximum adsorption capacity of 16.13 and $11.124 \mathrm{mg} / \mathrm{g}$ at $30^{\circ} \mathrm{C}$ for GS-IONPs and commercial one, respectively.

\subsection{Cadmium Adsorption Effects onto GS-Fe $\mathrm{O}_{3}-\mathrm{NP}_{\mathrm{S}}$}

Finally, the adsorption curves became smoother and more continuous. A large amount of space on the adsorbent material was available to hold the solute molecules for a long time, but as time passed, the space became unavailable to the same extent, due to the solute molecules' repulsive force quickly occupying it, resulting in a shortage of absorbent space on the material. Figure 7 indicates that contact durations are prolonged for liquids with high cadmium contents. To reach equilibrium, cadmium solutions with concentrations of 10, 15, 20, and $25 \mathrm{mg} / \mathrm{L}$ had to come into contact with GS-IONPs for 3, 7, 9, and $12 \mathrm{~h}$, respectively.

Skwarek and Janusz [29] reported on the adsorption of Cd(II) ions at the hydroxyapatite/electrolyte solution interface and the changes of the electrical double layer (EDL) structure in this system are presented. The adsorption of $\mathrm{Cd}(\mathrm{II})$ ions was calculated from the loss of their concentration from the solution using the radioisotope method. The adsorption was studied in the range of the initial concentration from 0.000001 to $0.001 \mathrm{~mol} / \mathrm{dm}^{3}$ and as the function of $\mathrm{pH}$ [29].

Dorota et al. [30] studied the sorption process of $\mathrm{Pb}(\mathrm{II})$ and $\mathrm{Cd}(\mathrm{II})$ ions from aqueous solutions in the presence of the complexing agent EDTA (ethylenediaminetetraacetic acid). They reported the influence of ionic strength, $\mathrm{pH}$, and solution interface. Electrophoretic 
mobility, surface charge density, and parameters for different concentrations of the electrolytes under question were also presented. Solution $\mathrm{pH}$ was changed from 3 to 10 . The effects of the concentration of the solution containing the above-noted complexes and of the ion exchange/solution phase contact time on the sorption capacities of the ion exchangers under consideration were studied. Kinetic parameters of the sorption process were also determined [30-35].

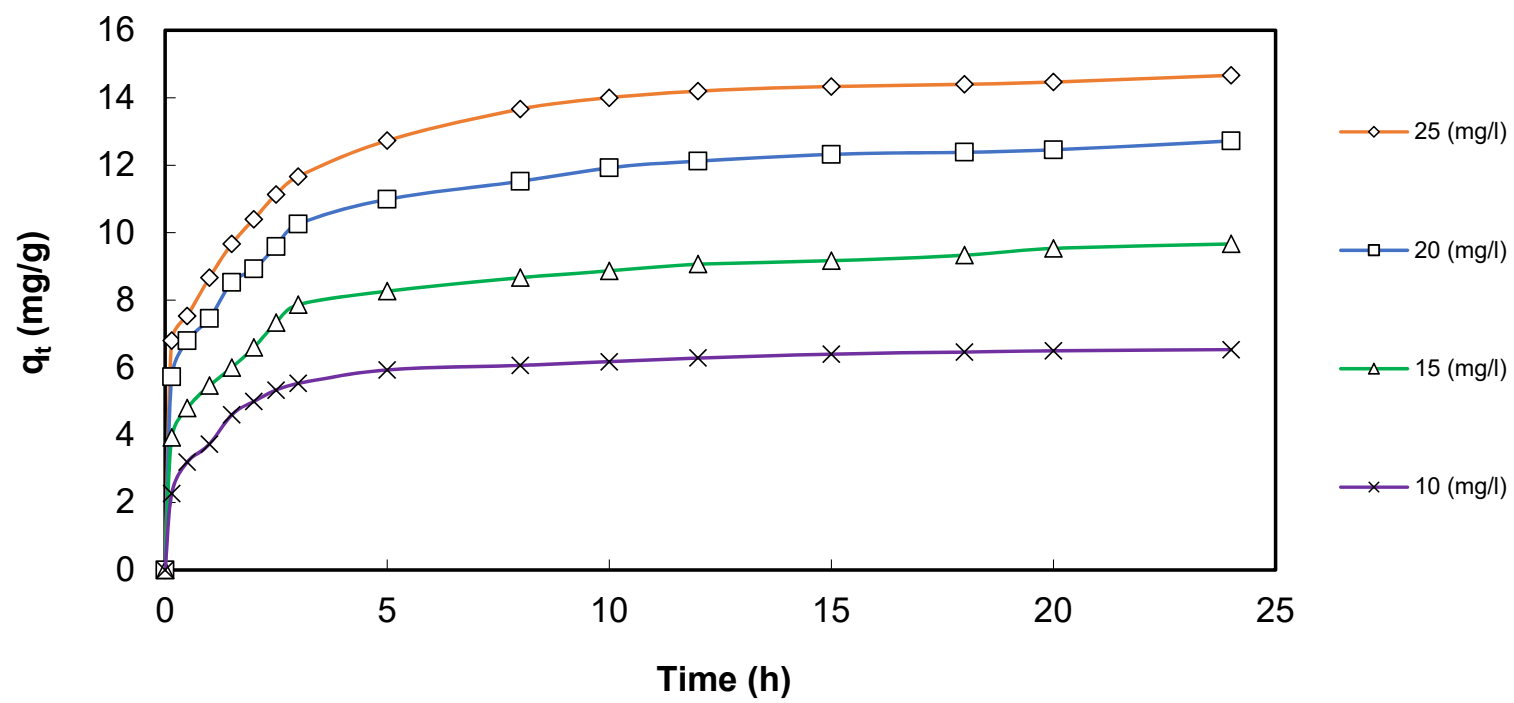

Figure 7. Adsorption capacity of Cd onto GS-IONPs in various contact durations.

\subsection{Comparison of Cadmium Adsorption onto Adsorbents}

Table 4 compared the adsorption capacities of cadmium onto various adsorbents reported in the literature and the current work.

Table 4. Summary of cadmium adsorption capacities of various adsorbents.

\begin{tabular}{ccccc}
\hline No. & Low-Cost Adsorbent & $\begin{array}{c}\text { Adsorption } \\
\text { Capacity }(\mathbf{m g} / \mathbf{g})\end{array}$ & $\begin{array}{c}\text { Isotherm } \\
\text { Model }\end{array}$ & Reference \\
\hline 1 & Rice husk & 8.85 & $\mathrm{~L}$ & {$[31]$} \\
\hline 2 & Sawdust & 9.29 & $\mathrm{~L}$ & {$[32]$} \\
\hline 3 & Walnut sawdust & 4.51 & $\mathrm{R}-\mathrm{P}$ & {$[33]$} \\
\hline 4 & Rice husk & 7 & $\mathrm{~L}$ & {$[32]$} \\
\hline 5 & Almond shell & 7 & $\mathrm{~L}$ & {$[34]$} \\
\hline 6 & oil palm fiber & 6.84 & $\mathrm{~L}$ & {$[35]$} \\
\hline 7 & Rice husk & 8.24 & $\mathrm{~L}$ & {$[34]$} \\
\hline 8 & cashew nut shell & 14.29 & $\mathrm{~L}$ & {$[35]$} \\
\hline 9 & Commercial charcoal & 11.12 & $\mathrm{~L}$ & This \\
study
\end{tabular}

\section{Conclusions}

Preparation and development of a new type of nanoparticle adsorbent from agriculture waste were carried out in this study (grape seeds). The best conditions for the manufacture of GS-IONPs were found to be a volume mixing ratio of $0.1 \mathrm{M} \mathrm{FeCl}_{2}$ with grape seed extract $(2: 1)$ at $70{ }^{\circ} \mathrm{C}$ and a solution $\mathrm{pH}$ of 3.8. The adsorption capability onto produced adsorbent (GS-IONPs) increased as the cadmium initial concentrations and contact time 
were increased. The Langmuir isotherm model was used to predict the adsorption of cadmium onto GS-IONPs and CC at $30^{\circ} \mathrm{C}$. The maximum adsorption capacity of 16.13 and $11.12 \mathrm{mg} / \mathrm{g}$ were obtained for both adsorbents, respectively.

Author Contributions: Conceptualization; M.H.I. and S.Z.Z.; methodology, A.J.M., S.Z.Z., M.H.I.; formal analysis, J.M.S., S.Z.Z., M.H.I.; resources; M.H.I.; data curation, S.Z.Z., M.H.I.; writingoriginal draft preparation, A.J.M.; writing—review and editing, S.Z.Z., M.H.I. and J.M.S.; project administration, M.H.I. and S.Z.Z.; funding acquisition, M.H.I., S.Z.Z. and JSM. All authors have read and agreed to the published version of the manuscript.

Funding: The authors wish to thank the Ministry of Higher Education Malaysia for their financial support through FRGS Grant FRGS/1/2016/STG03/UPM/02/6/5524945.

Institutional Review Board Statement: Not applicable.

Informed Consent Statement: Not applicable.

Data Availability Statement: The data that support this study will be shared upon reasonable request to the corresponding author.

Acknowledgments: We are grateful to the Iraqi Ministry of Science and Technology- materials research directorate for their assistance in providing laboratories during the experimental phase of our research.

Conflicts of Interest: The authors declare no conflict of interest.

\section{References}

1. Ashraf, M.W. Levels of Heavy Metals in Popular Cigarette Brands and Exposure to These Metals via Smoking. Sci. World J. 2012, 2012, 729430. [CrossRef]

2. Lamarque, J.-F.; Shindell, D.T.; Josse, B.; Young, P.J.; Cionni, I.; Eyring, V.; Bergmann, D.; Cameron-Smith, P.; Collins, W.J.; Doherty, R.; et al. The Atmospheric Chemistry and Climate Model Intercomparison Project (ACCMIP): Overview and description of models, simulations and climate diagnostics. Geosci. Model Dev. 2012, 6, 179-206. [CrossRef]

3. Ite, A.E.; Ubong, U.U.; Etesin, U.M.; Nsi, E.W.; Ukpong, E.J.; Ekanem, A.N.; Ufrt, U.F.; Udo, A.I. Heavy metals in Epiphytic Lichens and Mosses of Producing Communities of Ekel and Ibeno, Akwo Ibom State-Nigeria. Am. J. Environ. Prot. 2016, 4, 38-47.

4. Wu, W.; Wu, P.; Yang, F.; Sun, D.-L.; Zhang, D.-X.; Zhou, Y.-K. Assessment of heavy metal pollution and human health risks in urban soils around an electronics manufacturing facility. Sci. Total. Environ. 2018, 630, 53-61. [CrossRef]

5. Ite, A.E.; Udousoro, I.I.; Ibok, U.J. Distribution of Some Atmospheric Heavy Metals in Lichen and Moss Samples Collected from Eket and Ibeno Local Government Areas of Akwa Ibom State, Nigeria. Am. J. Environ. Prot. 2014, 2, 22-31. [CrossRef]

6. Adeola, A.A.; Kelechi, L.N.; Modupe, O.A. Assessment of Heavy Metals Pollution in Soils and Vegetation around Selected Industries in Lagos State, Nigeria. J. Geosci. Environ. Prot. 2015, 3, 11.

7. Rouf, Z.; Dar, I.Y.; Javaid, M.; Dar, M.Y.; Jehangir, A. Volatile Organic Compounds Emission from Building Sector and Its Adverse Effects on Human Health. In Ecological and Health Effects of Building Materials; Springer: Berlin, Germany, 2022; pp. 67-86.

8. Duruibe, J.O.; Ogwuegbu, M.O.C.; Egwurugwu, J.N. Heavy metal pollution and human biotoxic effects. Int. J. Phys. Sci. 2007, 2, 112-118.

9. Chioma, J.O.; Eka, B.E.; Matthew, O.W. Human Health Risk Assessment of Heavy Metal Contamination for Population via Consumption of Selected Vegetables and Tubers Grown in Farmlands in Rivers State, South-South Nigeria. J. Anal. Pharm. Res. 2016, 3, 00077.

10. Maciej, B.; Przemyslaw, R.; Moritz, F. Tapping Freshwaters for Methane and Energy. Environ. Sci. Technol. 2021, 55, 4183-4189.

11. Jinming, L.; Kaixing, F.; Deyou, Y.; Kiril, D.; Paul, W.; John, C. Review of Advances in Engineering Nanomaterial Adsorbents for Metal Removal and Recovery from Water: Synthesis and Microstructure Impacts. ACS ES T Eng. 2021, 1, $623-661$.

12. Deyou, Y.; Yijia, W.; Minghua, W.; Lu, Z.; Lili, W.; Huagang, N. Surface functionalization of cellulose with hyperbranched polyamide for efficient adsorption of organic dyes and heavy metals. J. Clean. Prod. 2019, 232, 774-783.

13. Mahdavi, S.; Jalali, M.; Afkhami, A. Removal of heavy metals from aqueous solutions using $\mathrm{Fe}_{3} \mathrm{O}_{4}, \mathrm{ZnO}$, and CuO nanoparticles. J. Nanopart. Res. 2012, 14, 846. [CrossRef]

14. Khan, S.B.; Rahman, M.M.; Marwani, H.M.; Asiri, A.M.; Alamry, A.K. An assessment of zinc oxide nanosheets as a selective adsorbent for cadmium. Nanoscale Res. Lett. 2013, 8, 377. [CrossRef] [PubMed]

15. Ghiloufi, I.; EI Ghoul, J.; Modwi, A.; EI Mir, L. Ga-doped ZnO for adsorption of heavy metals from aqueous solution. Mater. Sci. Semicond. Process. 2016, 42, 102-106. [CrossRef]

16. Schumacher, J.G.; Smith, D.C. Distribution of Mining-Related Trace Elements in Streambed and Flood-Plain Sediment along the Middle Big River and Tributaries in the Southeast Missouri Barite District, 2012-15; U.S. Geological Survey Scientific Investigations Report 2018-5103; USGS: Reston, VA, USA, 2018. [CrossRef] 
17. Wilson, D.N. Cadmium-Market trends and influences. In Cadmium 87. Proceedings of the 6th International Cadmium Conference; Cadmium Association: London, UK, 1988; pp. 9-16.

18. Robinson, B.; Russell, C.; Hedley, M.; Clothier, B. Cadmium adsorption by rhizobacteria: Implications for New Zealand pastureland. Agric. Ecosyst. Environ. 2001, 87, 315-321. [CrossRef]

19. TapVan, H.; HuongNguyen, L.; DangNguyen, V.; HoanNguyen, X.; HaiNguyen, T.; VinhNguyen, T.; Vigneswaran, S.; Rinklebe, J.; NguyenTran, H. Characteristics and mechanisms of cadmium adsorption onto biogenic aragonite shells-derived biosorbent: Batch and column studies. J. Environ. Manag. 2019, 241, 535-548.

20. Arteaga-Díaz, S.J.; Meramo-Hurtado, S.I.; León-Pulido, J.; Zuorro, A.; González-Delgado, A.D. Environmental Assessment of Large Scale Production of Magnetite $\left(\mathrm{Fe}_{3} \mathrm{O}_{4}\right)$ Nanoparticles via Coprecipitation. Appl. Sci. 2019, 9, 1682. [CrossRef]

21. Zuorro, A.; Iannone, A.; Natali, S.; Lavecchia, R. Green Synthesis of Silver Nanoparticles Using Bilberry and Red Currant Waste Extracts. Processes 2019, 7, 193. [CrossRef]

22. Nitin, N.; LaConte, L.; Zurkiya, O.; Hu, X.; Bao, G. Functionalization and peptide-based delivery of magnetic nanoparticles as an intracellular MRI contrast agent. JBIC J. Biol. Inorg. Chem. 2004, 9, 706-712. [CrossRef]

23. Adriannan, B.; Ewa, S.; Urban Margareta, H. Hydroxyapatite with magnetic core: Synthesis methods, properties, adsorption and medical applications. Adv. Colloid Interface Sci. 2021, 291, 102401.

24. Langmuir, I. The Adsorption of Gases on Plane Surfaces of Glass, Mica and Platinum. J. Am. Chem. Soc. 1918, 40, 1361-1403. [CrossRef]

25. Freundlich, H.M.F. Over the adsorption in solution. J. Phys. Chem. 1906, 57, 1100-1107.

26. Temkin, M.J.; Pyzhev, V. Recent Modifications to Langmuir Isotherms. Acta Physiochim. URSS 1940, 12, $217-225$.

27. Skwarek, E.; Janusz, W. Adsorption of Cd(II) ions at the hydroxyapatite/electrolyte solution interface. Sep. Sci. Technol. 2016, 51, 11-21. [CrossRef]

28. Dorota, K.; Ewa, S.; Zbigniew, H.; Władysław, J. The effect of adsorption of $\mathrm{Pb}(\mathrm{II})$ and Cd(II) ions in the presence of EDTA on characteristic of electrical double layer at the ion exchanger/ $\mathrm{NaCl}$ electrolyte solution interface. J. Colloid Interface Sci. 2009, 333, 448-456.

29. Kumar, U.; Bandyopadhyay, M. Sorption of cadmium from aqueous solution using pretreated rice husk. Bioresour. Technol. 2006, 97, 104-109. [CrossRef]

30. Taty-Costodes, V.; Fauduet, H.; Porte, C.; Delacroix, A. Removal of $\mathrm{Cd}(\mathrm{II})$ and $\mathrm{Pb}$ (II) ions, from aqueous solutions, by adsorption onto sawdust of Pinus sylvestris. J. Hazard. Mater. 2003, 105, 121-142. [CrossRef]

31. Bulut, Y.; Tez, Z. Removal of heavy metal ions by modified sawdust of walnut. Fresen Environ. Bull. 2003, 12, 1499-1504.

32. Mehrasbi, M.R.; Farahmandkia, Z.; Taghibeigloo, B.; Taromi, A. Adsorption of Lead and Cadmium from Aqueous Solution by Using Almond Shells. Water, Air Soil Pollut. 2008, 199, 343-351. [CrossRef]

33. Aimi, A.W.N.; Norain, I.; Aziyah, N.B.; Izza, N.H.; Vicinisvarri, I.; Hakim, M.H. Utilization of base modified oil palm fiber for removal of Cd(II) from aqueous solution. Res. J. Chem. Environ. 2014, 18, 26-32.

34. Haris, M.R.H.M.; Wahab, N.A.A.; Reng, C.W.; Azahari, B.; Sathasivam, K. The sorption of Cd(II) ions on mercerized rice husk and activated carbon. Turk. J. Chem. 2011, 35, 939-950.

35. Tangjunak, S.; Insuk, N.; Tontrakoon, J.; Udeye, V. Adsorption of Pb(ii) and Cd(II) ions from aqueous solutions by adsorption on activated carbon prepared from cashew nut shells. Int. Sci. Ind. 2009, 3, 1098-1104. [CrossRef] 